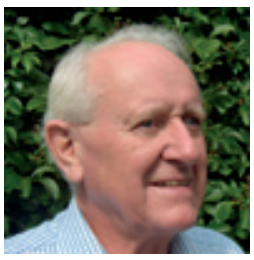

\title{
Rett til død når syk og døende?
}

\author{
I holdninger til aktiv dødshjelp inngår \\ tre aktører - pasienten (med sin selv- \\ bestemmelsesrett), legen (med sitt \\ lindringskrav) og samfunnet (med sitt \\ majoritetssyn) - samt loven, som for- \\ byr dødshjelp som eutanasi og assis- \\ tert suicid.
}

I holdningsforskningen om dødshjelp viser befolkingsundersøkelser i Skandinavia og den øvrige vestlige verden gjennomgående et klart flertall i størrelsesorden $60-80 \%$ for legeassistert dødshjelp, eutanasi som assistert suicid. I en nylig undersøkelse i Norge for foreningen Retten til en verdig død var $63 \%$ for eutanasi, $70 \%$ for assistert suicid (Synovate, 2008; N = 1001 telefonintervjuer). I sistnevnte tilfelle lød spørsmålet: «Hvor enig eller uenig er du i at en døende pasient, etter grundig overveielse, skal kunne få utskrevet en dødelig dose av sin lege som vedkommende selv kan velge å ta for å unngå store lidelser?»

Det grunnleggende spørsmål i denne artikkelen er individets rett til å bestemme over sin egen død ved å ta sitt liv, uaktet hvor gal eller feilaktig en slik handling måtte være i andres øyne. Denne retten er i dag akseptert for det vanlige selvmord og selvmordsforsøk når handlingen utføres uten hjelp fra andre. Medvirkning er imidlertid straffbart i Norge (men ikke i Sverige, Tyskland, Belgia og Sveits). Retten til død er således begrenset til egen utførelse og ikke ved samarbeid med andre. Men hva så hvis man er syk, full av smerte og døende og vil dø for egen hånd $-\operatorname{og} m a ̊$ ha hjelp til dette?

Når det gjelder legers holdning i Norge, er disse klart imot aktiv dødshjelp. I andre land er bildet betydelig mer variert. Her skal kort refereres fra tre sentrale undersøkelser med mer moderate holdninger.

En europeisk undersøkelse (Social Science \& Medicine, 2005), som omfattet syv forskjellige land (inkludert Australia) med forskjellige legegrupper, inneholdt blant annet følgende utsagn: «Bruk av medisiner i dødelig dose på eksplisitt anmodning fra pasienten er akseptabelt for terminalt syke pasienter med ekstrem, ukontrollerbar smerte eller annen lidelse.» Resultatene viste, i fallende enighetsfrekvens: Belgia $78 \%$, Nederland $77 \%$, Danmark $60 \%$, Sveits $56 \%$, Italia $36 \%$, Sverige $35 \%$ samt Australia $46 \%(\mathrm{~N}=10139$ postale intervjuer, svarprosent omkring 50). Resultatene indikerer således en majoritet med positiv holdning innen visse land i Europa, bortsett fra i Sverige og Italia. Særlig forskjellen mellom Sverige og Danmark er påfallende sett med norske øyne. Interessant $\mathrm{i}$ denne forbindelse er at et stort flertall i Statens medicinsk-etiska råd i Sverige i fjor gikk inn for legeassistert suicid.

I en senere svensk undersøkelse (Scandinavian Journal of Public Health, 2008) blant ulike legegrupper var hovedspørsmålet (basert på Oregon-modellens kriterier) om man var for eller imot legeassistert suicid, forutsatt at dette var blitt legalisert og at kriteriene var oppfylt. Spørsmålet lød: «Hvis disse kriterier er oppfylt, aksepterer du at leger forskriver medisin som en pasient kan ta i den hensikt å begå suicid smertefritt?» Svarene var: ja $34 \%$, nei $39 \%$, i tvil $25 \%$ $(\mathrm{N}=877$ postale intervjuer, svarprosent 74$)$. Igjen en tilsvarende svensk minoritet for assistert suicid, som i den foregående.

I en engelsk holdningsundersøkelse (Palliative Medicine, 2009) forelå det en sammenligning mellom både leger og befolkning. For eutanasi lød spørsmålet: «Først; en person med en uhelbredelig og smertefull sykdom som er dødelig, for eksempel en kreftdøende, synes du at hvis denne ber om det skal legen på lovlig vis tillates å avslutte dennes liv, eller ikke?» Befolkning for: $82 \%$, leger for: $34 \%$. For assistert suicid lød spørsmålet: «Og mener du at hvis en slik person ber om det, skal legen på lovlig vis tillates å gi denne dødelig medisin som vil gjøre det mulig for vedkommende å ta sitt eget liv?» Befolkning for: $62 \%$, leger for: $35 \%$ (befolkning $\mathrm{N}=2111$, leger $\mathrm{N}=3733$ ). Legenes holdning var her klart sammenfallende med svenske legers.

Altså - befolkningsdata fra sistnevnte undersøkelse viser samme positive tendens som fra øvrige vestlige land, mens legedata viser store variasjoner mellom de forskjellige europeiske land, med overveiende positivt flertall for dødshjelp. Dette gir en økende endring for aksept av dødshjelp blant leger i Europa. Resultater fra Oregon med assistert suicid viser at hyppigheten kun utgjør 1,5 promille av alle dødsfall. Overført til norske forhold tilsvarer dette 60 personer av 40000 døde årlig. Det er kun disse få som kan forventes å ville ønske seg en selvbestemt, verdig død.

Så til denne artikkels hovedspørsmål: «Rett til død når syk og døende?» Svaret blir selvsagt nei, ikke i dagens Norge. Jeg har lov til å ta mitt liv, men ikke med legens hjelp, ei heller med andres hjelp. Jeg kan få god smertestillende pleie, i nødsfall kanskje også bli dypt (terminalt) sedert, men kan ikke selv bestemme over min død når jeg så måtte ønske hvis behandling ikke lenger hjelper. Jeg kan reise til Sveits (Dignitas), der jeg straffritt kan få den nødvendige dose til selv å avslutte mitt liv, men klarer ikke det uten reisefølge fra mine nærmeste. Dette er straffbart for disse, selv utenfor Norge. Veien til en dødbringende resept er fortsatt lang. For lang.

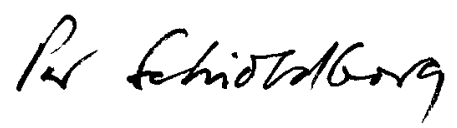

\section{I neste nummer:}

Trombolyse ved hjerneinfarkt

Hemolytisk anemi

Carotisstenose
Legevakt for sykehjem

Planteøstrogener

Overdosestatistikk 